Original Article

\title{
NEW VALIDATED METHOD DEVELOPMENT FOR THE ESTIMATION OF SULFAMETHOXAZOLE AND TRIMETHOPRIM IN BULK FORM BY VISIBLE SPECTROSCOPY
}

\author{
GAJJELA SWETHA, KUSUMA PRAVEEN KUMAR, KALAM SIRISHA*
}

Department of Pharmaceutical Analysis, Vaagdevi College of Pharmacy, Ramnagar, Hanamkonda, Warangal 506001, Telangana, India Email: ragisirisha@yahoo.com

Received: 11 Apr 2018 Revised and Accepted: 13 Nov 2018

\section{ABSTRACT}

Objective: To develop three novel, sensitive, simple validated visible spectrophotometric methods for the quantitative estimation of sulfamethoxazole (SMZ) and trimethoprim (TMP) in bulk form.

Methods: Methods were based on coupling the diazotized aromatic primary amino group of the studied drugs with o-phenylenediamine (OPD) in an acidic medium. The first two methods have been proposed for estimation of SMZ and rest for TMP. The resulting products were measured by spectrophotometric (method I, II and III) tools. The methods were validated as per ICH guidelines.

Results: In method I, the absorbance was measured at 482 and $457 \mathrm{~nm}$ with linearity ranges of 4.0-40.0 and 5.0-45.0 $\mu \mathrm{g} / \mathrm{ml}$ for SMZ. On the other hand, method III was devoted to estimate TMP spectrophotometrically at $457 \mathrm{~nm}$ with linearity range of 5-30 $\mu \mathrm{g} / \mathrm{ml}$. The $\mathrm{r}^{2}$ value for all methods were found to be 0.99 . The percentage recoveries of SMZ and TMP were found to be $97.98 \%, 97.56 \%$ and $97.55 \%$ respectively. The developed methods were subjected to detailed validation procedure in their pure forms.

Conclusion: The study concludes that visible spectrophotometric validation methods can be very efficient and economically promising technique for the quantitative analysis of SMZ and TMP in bulk form. The statistical analysis of data indicates that the developed methods were reproducible and specific. It was found that there is a good agreement between the obtained results and those obtained by the reported methods; moreover they can be used for the routine estimations of SMZ and TMP in bulk form.

Keywords: Sulfamethoxazole, Trimethoprim, Diazotization, Visible spectrophotometry, Validation

(C) 2018 The Authors. Published by Innovare Academic Sciences Pvt Ltd. This is an open access article under the CC BY license (http://creativecommons.org/licenses/by/4.0/) DOI: http://dx.doi.org/10.22159/ijpps.2018v10i12.26650

\section{INTRODUCTION}

Sulfonamides are extensively used for the treatment of different bacterial infections in human and veterinary practice [1]. Sulfonamides of pharmaceutical products usually consist, of one sulfonamide mixed with another drug that increases the power of the sulfonamide, e.g. the SMZ and TMP binary mixture. The synergistic antibacterial effect of TMP in combination with sulfonamide is well known both in the in vitro and in vivo situations [2].

SMZ is chemically 4-amino-N-(5-methylisoxazol-3-yl)-benzene sulfonamide (fig. 1) is a structural analog of para-aminobenzoic acid. Inhibiting the production of dihydrofolate intermediate binding through dihydropteroate synthetase interferes with the normal bacterial synthesis of folic acid, which inhibits the folate-dependent metabolic process for bacterial growth [3]

TMP is designated chemically as 5-(3,4,5-trimethoxy benzyl) pyrimidine-2,4-diamine (fig. 2) which binds dihydrofolate reductase and decrease the levels of tetrahydrofolic acid which an essential precursor in the thymidine synthesis pathway, inhibits bacterial DNA synthesis. TMP affinity for bacterial dihydrofolate reductase is several thousand times greater than its affinity for human dihydrofolate reductase [4].<smiles>Cc1cc(NS(=O)(=O)c2ccc(N)cc2)no1</smiles>

Fig. 1: Structure of SMZ<smiles>COc1cc(Cc2cnc(N)nc2N)cc(OC)c1OC</smiles>

Fig. 2: Structure of TMP

Among the various methods available for the estimation of these drugs in literature survey, such as charge transfer complexation [5], uvvisible spectrophotometry [6-16], square wave voltametry [17], rapid UPLC [18], HPLC [19], chemical evaluation [20], spectroflourimetry [21] and flow injection system/HPLC with potentiometry [22], colorimetric sensors have attracted increasing considerations for their convenience of visual observation and simple operations in recent years [23-25]. OPD and its derivatives have been widely used in the estimation of enzymes and drugs [26, 27].

From literature, hitherto there are no visible spectrophotometric methods reported for the estimation of SMZ and TMP using OPD through diazotization followed by coupling reaction which encouraged us to develop these methods. Hence, for the first time, we describe few simple, sensitive, cost-effective, novel methods using OPD to assay these drugs in bulk samples.

\section{MATERIALS AND METHODS}

Apparatus

The visible spectra of drug solutions were recorded on a Shimadzu $1800 \mathrm{UV} /$ Vis spectrophotometer at room temperature in $1 \mathrm{~cm}$ quartz cell. The wavelength range was from 200 to $800 \mathrm{~nm}$. For spectral data acquisition and processing UV probe software was used. 


\section{Chemicals and reagents}

SMZ and TMP bulk drugs were obtained from KP Labs, hyderabad, telangana state, india. All chemicals used are of analytical grade. Sodium nitrite and sodium hydroxide pellets were obtained from finar chemicals ltd, hyderabad, telangana state, india. Hydrochloric acid, OPD, methanol, and sulfamicacid were obtained from fine chem private limited, hyderabad, telangana state, SD fine chem ltd and qualigen fine chemicals, mumbai, india respectively.

\section{Preparation of standard stock solutions [28-30]}

Method I: About $100 \mathrm{mg}$ of SMZ was weighed accurately and dissolved in $30 \mathrm{ml}$ of $2 \mathrm{~mol}$ hydrochloric acid in a $100 \mathrm{ml}$ volumetric flask and diluted up to the mark with water $(1000 \mu \mathrm{g} / \mathrm{ml})$. The final concentration of SMZ was made up to $100 \mu \mathrm{g} / \mathrm{ml}$ with distilled water.

Method II and III: About $10 \mathrm{mg}$ of SMZ and TMP was weighed separately, accurately and dissolved in few $\mathrm{ml}$ of methanol in a 100 $\mathrm{ml}$ volumetric flask and diluted up to the mark with methanol (100 $\mu \mathrm{g} / \mathrm{ml}$ ).

\section{Method development}

Aliquots of SMZ in distilled water ranging from $0.4-4.0 \mathrm{ml}(100$ $\mu \mathrm{g} / \mathrm{ml})$, methanol ranging from $0.5-4.5 \mathrm{ml}(100 \mu \mathrm{g} / \mathrm{ml})$ and methanol for TMP ranging from $0.5-3.0 \mathrm{ml}(100 \mu \mathrm{g} / \mathrm{ml})$ were transferred into a series of $10 \mathrm{ml}$ volumetric flasks separately. To each flask, $1 \mathrm{ml}$ of ice cold sodium nitrite $(0.1 \% \mathrm{w} / \mathrm{v})$ and $1 \mathrm{ml}$ of 2 mol hydrochloric acid were added at room temperature and cooled in an ice bath. After $5 \mathrm{~min}, 1 \mathrm{ml}$ of sulphamic acid $(0.2 \% \mathrm{w} / \mathrm{v})$ and 1 $\mathrm{ml}$ of OPD reagent were added. The volumes were made up to the mark with distilled water (method I) and methanol (method II and III). The final concentrations were ranging from 4-40 (method I), 545 (method II) and 5-30 $\mathrm{gg} / \mathrm{ml}$ (method III) respectively. The absorbance of an orange-yellow coloured chromogen was measured at 482 and $457 \mathrm{~nm}$ for SMZ and $457 \mathrm{~nm}$ for TMP respectively against a reagent blank. The amount of SMZ and TMP present in the sample was computed from the calibration curve.<smiles>Cc1cc(NS(=O)(=O)c2ccc(N)cc2)no1</smiles>

Sulfamethoxazole<smiles>Cc1cc(NS(=O)(=O)c2ccc([N+](=O)[O-])cc2)no1</smiles>

Diazonium salt of Sulfamethoxazole<smiles>Cc1cc(NS(=O)(=O)c2ccc(N=Nc3ccc(N)c(N)c3)cc2)no1</smiles>

Scheme 1: Proposed reaction scheme for methods I and II<smiles>COc1cc(Cc2cnc(N)nc2N)cc(OC)c1OC</smiles><smiles>COc1cc(Cc2cnc(N)nc2[N+]#N)cc(OC)c1OC</smiles>

Diazonium salt of Trimethoprim
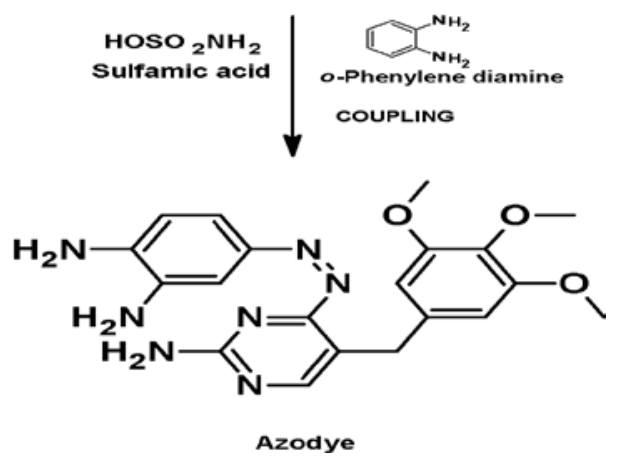

Scheme 2: Proposed reaction scheme for method III

\section{Method validation}

\section{Linearity}

Linearity was studied in the concentration range of $4-40 \mu \mathrm{g} / \mathrm{ml}$ in distilled water [method I], 5-45 $\mu \mathrm{g} / \mathrm{ml}$ in methanol [method II] and 5-30 $\mu \mathrm{g} / \mathrm{ml}$ in methanol [method III]. The absorbance of an orange-yellow coloured chromogen was measured at $482 \mathrm{~nm}$ [method I], $457 \mathrm{~nm}$ [method II and III] against a reagent blank. The amount of SMZ, TMP present in the sample was computed from the calibration curve.

\section{Precision}

Repeatability of the method was performed by measuring the absorbance of the same sample in replicates of six.

\section{Method I}

Intraday precision of SMZ was performed by measuring the absorbance of 3 different samples $(8,16$ and $24 \mu \mathrm{g} / \mathrm{ml})$ on 3 different times (morning, afternoon and evening) in the same day.

Interday precision was performed by injecting 3 different samples $(8,16,24 \mu \mathrm{g} / \mathrm{ml})$ on 3 different days.

\section{Method II}

Intraday precision of SMZ was performed by measuring the absorbance of 3 different samples $(10,20$, and $30 \mu \mathrm{g} / \mathrm{ml})$ on 3 different times (morning, afternoon and evening) in the same day.

Interday precision was performed by measuring the absorbance of 3 different samples $(10,20$, and $30 \mu \mathrm{g} / \mathrm{ml})$ on 3 different days.

\section{Method III}

Intraday precision of SMZ was performed by measuring the absorbance of 3 different samples $(5,15$ and $25 \mu \mathrm{g} / \mathrm{ml}$ ) on 3 different times (morning, afternoon and evening) in the same day. 
Interday precision was performed by measuring the absorbance of 3 different samples $(5,15$, and $25 \mu \mathrm{g} / \mathrm{ml})$ on 3 different days.

$$
\% \text { RSD }=\frac{\mathrm{SD} \times 100}{\text { Mean }}
$$

Where SD $\rightarrow$ standard deviation

\section{Robustness}

Robustness of the developed method is a measure of its capacity to remain unaffected by small, but deliberate variations in method parameters like temperature, minor variations in $\mathrm{p}^{\mathrm{H}}$ of solvent, $\lambda_{\max }$, etc.

\section{Ruggedness}

It is the degree of reproducibility of test results obtained by the analysis of same samples under a variety of conditions, such as different laboratories, analysts, instruments, lots of reagents, days, etc. Ruggedness of the developed method is determined by analyzing the same samples prepared by different analysts and also using different instruments.

\section{Detection and quantitation limits [LOD and LOQ]}

LOD is the smallest amount of sample that can be detected but not essentially quantified.
LOQ is the smallest amount of sample that can be quantified.

LOD and LOQ are calculated from the formula:

$\mathrm{LOD}=3.3 \times \sigma / \mathrm{S}$

$\mathrm{LOQ}=10 \times \sigma / \mathrm{S}$

Where, $\sigma \rightarrow$ Standard deviation and $\mathrm{S} \rightarrow$ slope

\section{RESULTS}

The methods were validated as per ICH guidelines [31]

Three visible spectrophotometric methods has been proposed involving diazotization of the active aromatic amino groups of SMZ and TMP moieties and subsequent coupling of the azocompounds to orange-yellow coloured products having a maximum absorbance at 482,457 (the method I and II) and 457 $\mathrm{nm}$ (method III) respectively.

The structures of the drugs SMZ and TMP are represented in fig. 1 and 2 and visible spectrum showed $\lambda_{\max }$ of $482 \mathrm{~nm}$ for the azo dye formed between SMZ and OPD in distilled water (method I, scheme 1, fig. 3), $457 \mathrm{~nm}$ in methanol (method II, scheme 1, fig. 4) and $457 \mathrm{~nm}$ for the azo dye of TMP in methanol (method III, scheme 2, fig. 5).

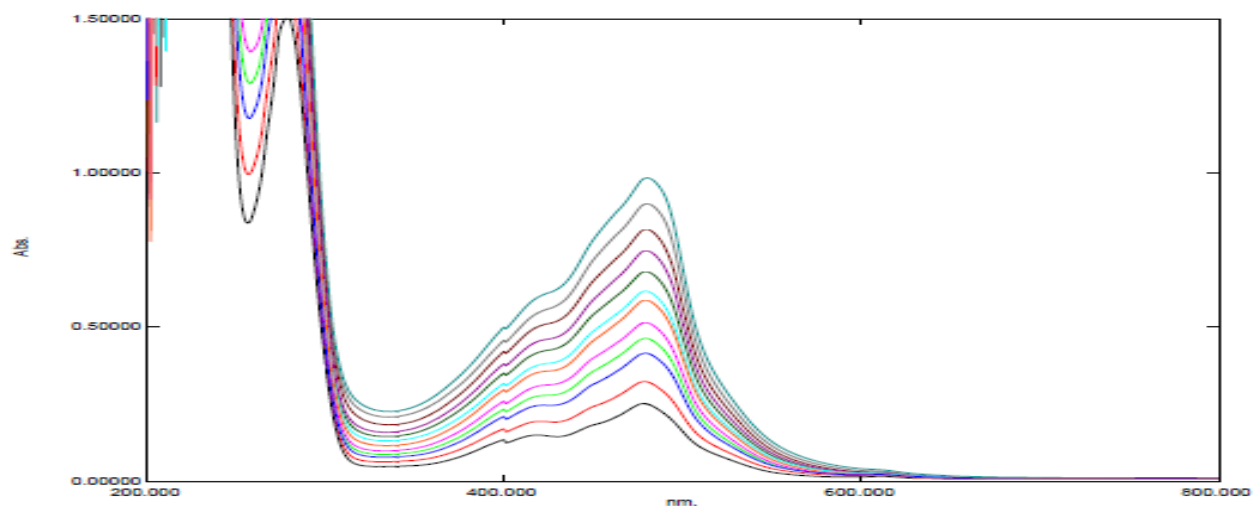

Fig. 3: Spectra showing overlain of azodye of SMZ in distilled water $(4-40 \mu \mathrm{g} / \mathrm{ml})$

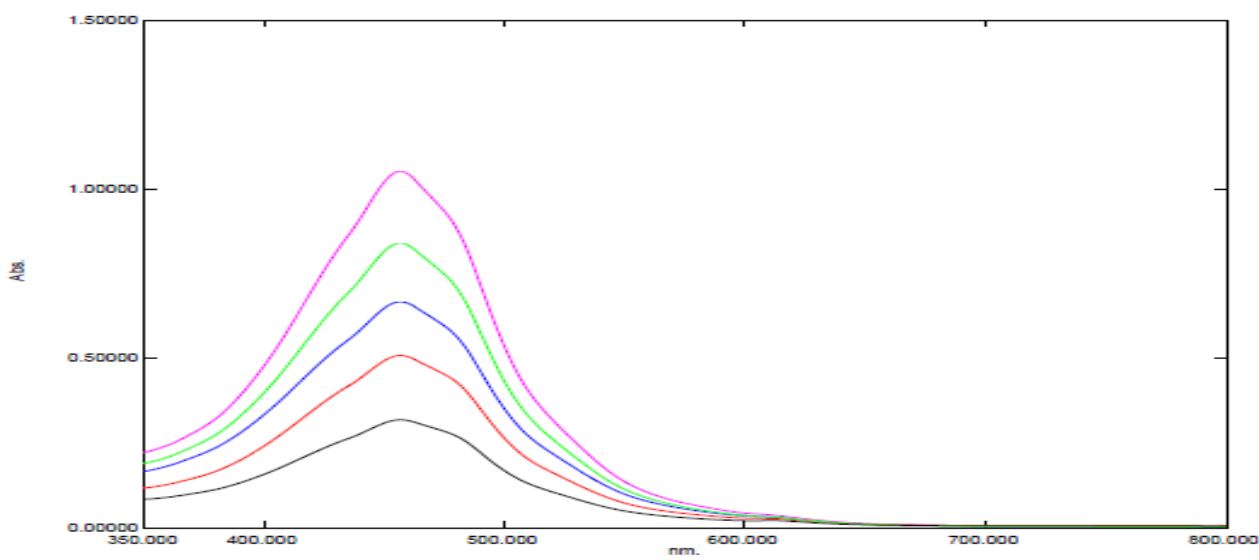

Fig. 4: Spectra showing overlain of SMZ azodye in methanol $(5-45 \mu \mathrm{g} / \mathrm{ml})$

\section{Linearity and range}

The calibration plots obtained by plotting the absorbance (methods I, II and III) against the final concentrations (in $\mu \mathrm{g} / \mathrm{ml}$ ) were found to be linear over the concentration ranges presented in table 1 , and the graphs pertaining to them are depicted in fig. 6-8. The validity of the developed methods was proven by statistical regression line [32], and it was found that percentage relative standard deviation (\% RSD) was small while correlation coefficient values ( $r$ ) were high (table 9) indicating the good linearity of calibration plots. 


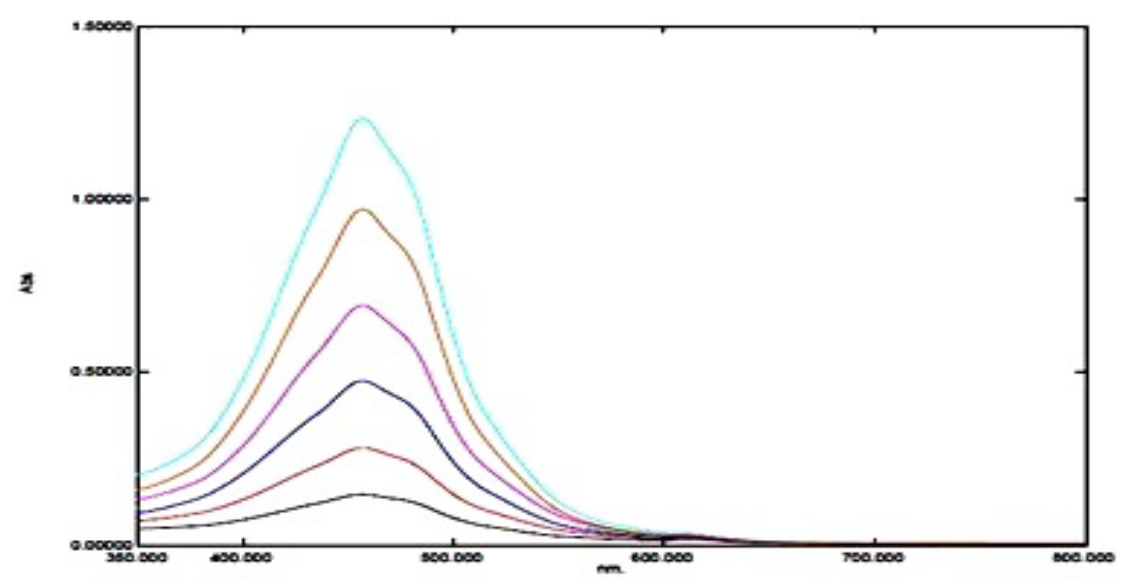

Fig. 5: Spectra showing overlain of azodye of TMP in methanol $(5-30 \mu \mathrm{g} / \mathrm{ml})$

Table 1: Linearity results for SMZ and TMP

\begin{tabular}{|c|c|c|c|c|c|c|}
\hline \multirow[t]{3}{*}{ S. No. } & \multicolumn{2}{|l|}{ method I } & \multicolumn{2}{|l|}{ method II } & \multicolumn{2}{|l|}{ method III } \\
\hline & \multicolumn{2}{|c|}{ SMZ in distilled water } & \multicolumn{2}{|c|}{ SMZ in methanol } & \multicolumn{2}{|c|}{ TMP in methanol } \\
\hline & Concentration & Absorbance* & Concentration & Absorbance* & Concentration & absorbance* \\
\hline 1 & $4 \mu \mathrm{g} / \mathrm{ml}$ & $0.133 \pm 0.001$ & $5 \mu \mathrm{g} / \mathrm{ml}$ & $0.252 \pm 0.002$ & $5 \mu \mathrm{g} / \mathrm{ml}$ & $0.146 \pm 0.001$ \\
\hline 2 & $8 \mu \mathrm{g} / \mathrm{ml}$ & $0.244 \pm 0.002$ & $10 \mu \mathrm{g} / \mathrm{ml}$ & $0.317 \pm 0.002$ & $10 \mu \mathrm{g} / \mathrm{ml}$ & $0.291 \pm 0.001$ \\
\hline 3 & $12 \mu \mathrm{g} / \mathrm{ml}$ & $0.329 \pm 0.004$ & $15 \mu \mathrm{g} / \mathrm{ml}$ & $0.422 \pm 0.005$ & $15 \mu \mathrm{g} / \mathrm{ml}$ & $0.470 \pm 0.001$ \\
\hline 4 & $16 \mu \mathrm{g} / \mathrm{ml}$ & $0.429 \pm 0.002$ & $20 \mu \mathrm{g} / \mathrm{ml}$ & $0.507 \pm 0.003$ & $20 \mu \mathrm{g} / \mathrm{ml}$ & $0.592 \pm 0.003$ \\
\hline 5 & $20 \mu \mathrm{g} / \mathrm{ml}$ & $0.518 \pm 0.001$ & $25 \mu \mathrm{g} / \mathrm{ml}$ & $0.592 \pm 0.001$ & $25 \mu \mathrm{g} / \mathrm{ml}$ & $0.778 \pm 0.002$ \\
\hline 6 & $24 \mu \mathrm{g} / \mathrm{ml}$ & $0.618 \pm 0.002$ & $30 \mu \mathrm{g} / \mathrm{ml}$ & $0.667 \pm 0.001$ & $30 \mu \mathrm{g} / \mathrm{ml}$ & $0.969 \pm 0.003$ \\
\hline 7 & $28 \mu \mathrm{g} / \mathrm{ml}$ & $0.702 \pm 0.001$ & $35 \mu \mathrm{g} / \mathrm{ml}$ & $0.725 \pm 0.002$ & - & - \\
\hline 8 & $32 \mu \mathrm{g} / \mathrm{ml}$ & $0.787 \pm 0.001$ & $40 \mu \mathrm{g} / \mathrm{ml}$ & $0.84 \pm 0.004$ & - & - \\
\hline 9 & $36 \mu \mathrm{g} / \mathrm{ml}$ & $0.870 \pm 0.004$ & $45 \mu \mathrm{g} / \mathrm{ml}$ & $0.928 \pm 0.004$ & - & - \\
\hline
\end{tabular}

*values given in table are the mean \pm SD of three replicate experiments

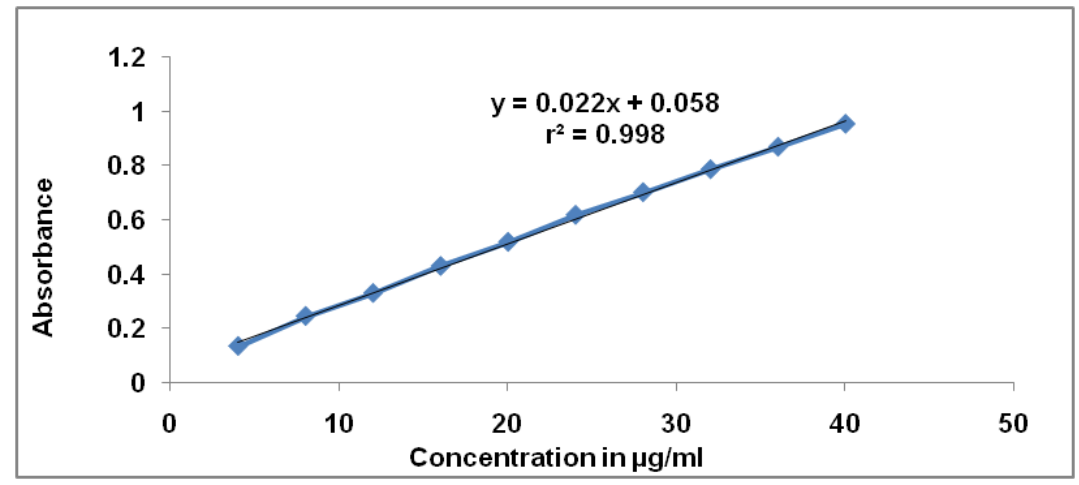

Fig. 6: Linearity graph for SMZ [method-I]

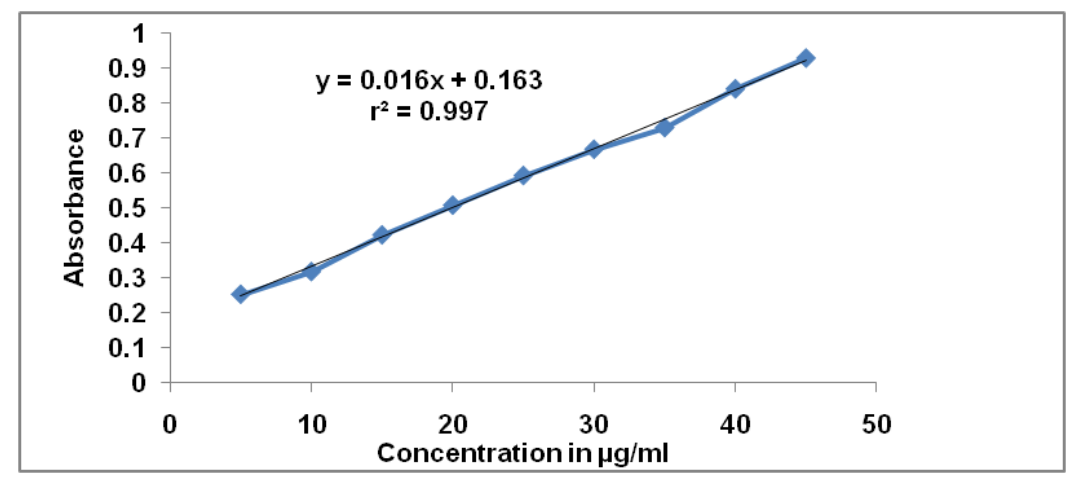

Fig. 7: Calibration curve of azodye of SMZ [method-II] 


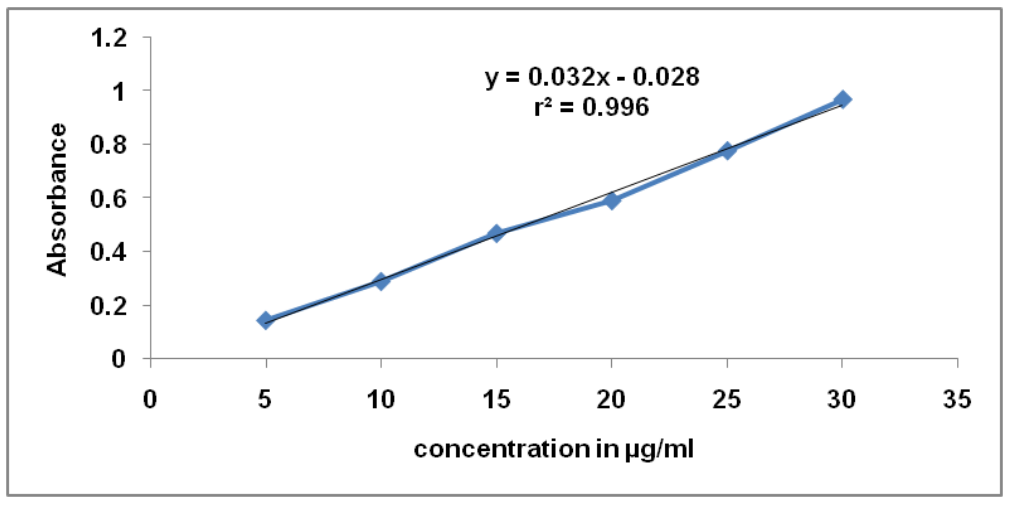

Fig. 8: Linearity graph for azodye of TMP [method-III]

\section{Precision and accuracy}

The proposed method's accuracy could be demonstrated by comparing the obtained results with those obtained by comparison methods [33] showing good agreement between them (table 2). The \%
Recovery in all the three methods was found to be within the limits. On the other hand, precision was tested by using three different concentrations of the tested drugs whether during $1 \mathrm{~d}$ (intra-day precision), or on three different times (inter-day precision). Remarkable precision is noted from low RSD values shown in table 2 .

Table 2: Precision results for SMZ and TMP

\begin{tabular}{|c|c|c|c|c|c|c|c|}
\hline \multirow{3}{*}{$\begin{array}{l}\text { S. } \\
\text { No. }\end{array}$} & \multicolumn{3}{|l|}{ Method I } & \multicolumn{2}{|l|}{ Method II } & \multicolumn{2}{|l|}{ Method III } \\
\hline & \multicolumn{3}{|c|}{ SMZ (distilled water)* } & \multicolumn{2}{|c|}{ SMZ (methanol)* } & \multicolumn{2}{|c|}{ TMP (methanol)* } \\
\hline & Standard & Intraday & Interday & Intraday & Interday & Intraday & Interday \\
\hline 1 & Set-1 & $0.436 \pm 0.005$ & $0.448 \pm 0.008$ & $0.515 \pm 0.006$ & $0.524 \pm 0.008$ & $0.468 \pm 0.006$ & $0.477 \pm 0.009$ \\
\hline 2 & Set-2 & $0.442 \pm 0.008$ & $0.453 \pm 0.007$ & $0.519 \pm 0.006$ & $0.529 \pm 0.009$ & $0.472 \pm 0.007$ & $0.482 \pm 0.008$ \\
\hline 3 & Set-3 & $0.448 \pm 0.006$ & $0.461 \pm 0.009$ & $0.524 \pm 0.008$ & $0.535 \pm 0.008$ & $0.477 \pm 0.008$ & $0.486 \pm 0.009$ \\
\hline 4 & $\%$ RSD & 0.184 & 1.079 & 0.157 & 1.531 & 0.259 & 1.919 \\
\hline
\end{tabular}

*values given in table are the mean \pm SD of six observations

Table 3: Accuracy results

\begin{tabular}{llll}
\hline Method & Amount added & Amount found* $(\boldsymbol{\mu g} / \mathbf{m l})$ & \% Recovery* \\
\hline \multirow{3}{*}{ Method-I } & $8 \mu \mathrm{g} / \mathrm{ml}$ & $7.85 \pm 0.01$ & $98.12 \pm 0.238$ \\
& $10 \mu \mathrm{g} / \mathrm{ml}$ & $9.75 \pm 0.01$ & $97.5 \pm 0.157$ \\
& $12 \mu \mathrm{g} / \mathrm{ml}$ & $11.80 \pm 0.02$ & $98.33 \pm 0.345$ \\
& $5 \mu \mathrm{g} / \mathrm{ml}$ & $4.9 \pm 0.02$ & $98.0 \pm 0.348$ \\
Method-II & $10 \mu \mathrm{g} / \mathrm{ml}$ & $9.85 \pm 0.03$ & $98.5 \pm 0.510$ \\
& $15 \mu \mathrm{g} / \mathrm{ml}$ & $4.6 \pm 0.04$ & $97.33 \pm 0.249$ \\
Method-III & $5 \mu \mathrm{g} / \mathrm{ml}$ & $9.8 \pm \pm 0.03$ & $97.0 \pm 0.500$ \\
& $10 \mu \mathrm{g} / \mathrm{ml}$ & $14.65 \pm 0.04$ & $98.0 \pm 0.228$ \\
\end{tabular}

*values given in the table are the mean $\pm \mathrm{SD}$ of three replicate experiments

\section{Robustness}

It was established by the consistency of absorbance with deliberately small changes in different experimental conditions. Regarding method, I,
II and III, these changes involve wavelength $( \pm 2 \mathrm{~nm})$ and temperature results presented in tables 4 to 6 . These small changes which can occur during the experimental process didn't influence the absorbance of the studied drugs, demonstrating the robustness of these methods.

Table 4: Robustness study of method-I $(16 \mu \mathrm{g} / \mathrm{ml})$

\begin{tabular}{|c|c|c|c|}
\hline Change in wavelength $( \pm 2 \mathrm{~nm})$ & Absorbance* & Change in temperature $\left({ }^{\circ} \mathrm{C}\right)$ & Absorbance* \\
\hline 480 & $0.428 \pm 0.002$ & room temperature & $0.429 \pm 0.002$ \\
\hline 481 & $0.429 \pm 0.002$ & Sunlight & $0.431 \pm 0.001$ \\
\hline 482 & $0.429 \pm 0.001$ & Refrigerator & $0.438 \pm 0.001$ \\
\hline 483 & $0.428 \pm 0.002$ & - & - \\
\hline 484 & $0.427 \pm 0.003$ & - & - \\
\hline
\end{tabular}

*values given in table are the mean $\pm \mathrm{SD}$ of three observations 
Table 5: Robustness study of method-II $(20 \mu \mathrm{g} / \mathrm{ml})$

\begin{tabular}{|c|c|c|c|}
\hline Change in wavelength $( \pm 2 \mathrm{~nm})$ & Absorbance* & Change in temperature $\left({ }^{\circ} \mathrm{C}\right)$ & Absorbance* \\
\hline 455 & $0.507 \pm 0.001$ & room temperature & $0.507 \pm 0.003$ \\
\hline 456 & $0.507 \pm 0.002$ & Sunlight & $0.515 \pm 0.002$ \\
\hline 457 & $0.508 \pm 0.002$ & Refrigerator & $0.509 \pm 0.001$ \\
\hline 458 & $0.507 \pm 0.001$ & - & - \\
\hline 459 & $0.506 \pm 0.002$ & - & - \\
\hline
\end{tabular}

*values given in table are the mean \pm SD of three observations

Table 6: Robustness study of method-III $(15 \mu \mathrm{g} / \mathrm{ml})$

\begin{tabular}{|c|c|c|c|}
\hline Change in wavelength $( \pm 2 \mathrm{~nm})$ & Absorbance* & Change in temperature $\left({ }^{\circ} \mathrm{C}\right)$ & Absorbance* \\
\hline 455 & $0.470 \pm 0.001$ & room temperature & $0.471 \pm 0.001$ \\
\hline 456 & $0.471 \pm 0.001$ & Sunlight & $0.482 \pm 0.003$ \\
\hline 457 & $0.471 \pm 0.002$ & Refrigerator & $0.476 \pm 0.002$ \\
\hline 458 & $0.470 \pm 0.001$ & - & - \\
\hline 459 & $0.469 \pm 0.003$ & - & - \\
\hline
\end{tabular}

*values given in table are the mean \pm SD of three observations

\section{Ruggedness}

Ruggedness results were presented in table 7. All proposed methods were found to be reproducible when subjected to analyst and instrumental variation.

\section{LOD and LOQ}

LOD and LOQ were determined in accordance to ICH requirements and their values are presented in table 8. Method I was found to be more sensitive than method II and III as it displayed the lowest LOD and LOQ values.

Table 7: Ruggedness

\begin{tabular}{llll}
\hline Variation & Method-I* & Method-II* & Method-III* \\
\hline Actual & $0.329 \pm 0.001$ & $0.317 \pm 0.002$ & $0.592 \pm 0.001$ \\
Analyst to analyst & $0.329 \pm 0.002$ & $0.320 \pm 0.001$ & $0.590 \pm 0.001$ \\
Instrument to instrument & $0.330 \pm 0.001$ & $0.319 \pm 0.001$ \\
(Libra biochrome) & & & $0.594 \pm 0.002$ \\
\hline
\end{tabular}

*values given in the table are the mean \pm SD of three replicate experiments

Table 8: LOD and LOQ

\begin{tabular}{llll}
\hline Parameter & Method-I & Method-II & Method-III \\
\hline LOD & $1.51 \mu \mathrm{g} / \mathrm{ml}$ & $2.127 \mu \mathrm{g} / \mathrm{ml}$ & $2.462 \mu \mathrm{g} / \mathrm{ml}$ \\
LOQ & $4.57 \mu \mathrm{g} / \mathrm{ml}$ & $6.447 \mu \mathrm{g} / \mathrm{ml}$ & $7.462 \mu \mathrm{g} / \mathrm{ml}$ \\
\hline
\end{tabular}

Table 9: Analytical performance data for the proposed methods

\begin{tabular}{|c|c|c|c|}
\hline Parameters & Method-I & Method-II & Method-III \\
\hline Wavelength (nm) & 482 & 457 & 457 \\
\hline Linearity $(\mu \mathrm{g} / \mathrm{ml})$ & $4-40$ & $5-45$ & $5-30$ \\
\hline Regression equation $(y=m x+c)$ & $y=0.022 x+0.058$ & $y=0.016 x+0.163$ & $y=0.032 x-0.028$ \\
\hline Slope (m) & 0.022 & 0.016 & 0.032 \\
\hline Intercept (c) & 0.058 & 0.163 & 0.028 \\
\hline $\begin{array}{l}\text { Correlation coefficient } \\
\left(\mathrm{r}^{2}\right)\end{array}$ & 0.998 & 0.997 & 0.996 \\
\hline $\begin{array}{l}\text { Intraday precision } \\
\text { (\% RSD) }\end{array}$ & 0.1846 & 0.1571 & 0.2593 \\
\hline $\begin{array}{l}\text { Interday precision } \\
\text { (\% RSD) }\end{array}$ & 1.079 & 1.5311 & 1.9197 \\
\hline \% Recovery & 97.94 & 97.56 & 97.55 \\
\hline $\mathrm{LOD}(\mu \mathrm{g} / \mathrm{ml})$ & 1.51 & 2.127 & 2.462 \\
\hline $\mathrm{LOQ}(\mu \mathrm{g} / \mathrm{ml})$ & 4.57 & 6.447 & 7.462 \\
\hline
\end{tabular}

\section{DISCUSSION}

The proposed methods involve the diazotization of SMZ and TMP, followed by the addition of OPD along with sulfamic acid for coupling reaction. The validity of the proposed procedure for the determination of the studied drugs in their pure state was tested by analyzing these drugs using the proposed procedure and the official methods [34, 35]. The absorption spectrum of the orange-yellow coloured products having maximum absorbance at 482, 457 (method I and II) and $457 \mathrm{~nm}$ (method III) respectively, were shown in fig. $3,4,5$. The colorless reagent blank has practically negligible absorption at this wavelength. The optical characteristics and precision data for the both drugs tested in this study are given in table 2 and 9. 
The developed methods succeeded to increase absorption maxima through the formation of colored products between the primary amino group of both drugs and OPD reagent. The formed azo dyes exhibit both bathochromic and hyperchromic shift (fig. 3, 4 and 5). Hyperchromic shift could be explained by the marked increase in the conjugation system through azo linkage which leads to enhancement of absorbance readings of both drugs. While bathochromic shift could result due to the formation of more energetic products, since the reaction takes place in acidic medium, yielding positive charges held by the primary amino groups of the formed products, hence rendering them more energetic and as expected their need for energy to be excited for higher energy levels will remarkably decrease, and as a consequence a positive shift in the wavelength results.

$3.0 \mathrm{ml} 2.0 \mathrm{~mol} / \mathrm{dm} 3$ hydrochloric acid; $3.0 \mathrm{ml} 0.1 \%$ ice-cold sodium nitrite solution; were used for diazotization; $3.0 \mathrm{ml} 0.2 \%$ sulfamic acid solution; and $3.0 \mathrm{ml} 3 \%$ OPD solution were used to develop an orange-yellow coloured azo dye. The excess sodium nitrite during diazotization can be removed by the addition of sulfamic acid solution; an excess of sulfamic acid has no effect on color intensity.

Dissolution of the azo dye was tested with various solvents such as water, ethanol, methanol, hydrochloric acid, sulfuric acid, acetic acid and acetonitrile. In an acidic medium, both drugs react with nitrite to form a diazonium salt, which, when coupled with OPD in the presence of sulfamic acid, yields orange-yellow azo dye complex gives with maximum absorption at 482,457 (the method I and II) and $457 \mathrm{~nm}$ (method III) respectively. In all cases, the azo product formed was stable for $>2 \mathrm{~d}$. The stability of the azo product resulting from the proposed methods was studied in the different temperature conditions like room temperature, sunlight and refrigerator. The product was found to be stable above the mentioned conditions and the results were reproducible. However, a temperature range of $20-30{ }^{\circ} \mathrm{C}$ (room temperature) is preferred for the present experimental conditions.

The accuracy of the developed methods was determined by recovery studies. Percentage recovery was found to be 97.94 in the method I, 97.56 in method II for SMZ and 97.55 in method III for TMP respectively. Results were found to be within the accepted limit and percentage RSD of less than 2. This confirmed that the proposed method was found to be accurate. Repeatability of the method was studied by precision experiments. \% RSD was found to be 0.184 and 1.079 (the method I); 0.157 and 1.531 (method II); 0.259 and 1.919 (method III); former two methods for SMZ, rest for TMP in intra and inter-day precision respectively. The \% RSD value in ruggedness was found to be $0.329,0.330$ (method I, analyst to analyst and instrument to instrument); $0.320,0.319$ (method II, analyst to analyst and instrument to instrument) for SMZ and 0.590, 0.594 (method III, analyst to analyst and instrument to instrument) (table 7) for TMP in six replicates of absorbance. The low percentage RSD value illustrates the ruggedness of the method.

LOD and LOQ were estimated from the standard deviation of the Yintercepts and slope of the calibration curve of SMZ in distilled water (method I, fig.3), in methanol (method II, fig. 4) and TMP in methanol (method III, fig. 5). This showed that the developed methods can detect and quantify very low concentrations of SMZ and TMP; therefore obtained data proves the sensitivity of the developed methods for quantification of SMZ and TMP. Among the developed methods (I, II and III) method I was proven to be more sensitive due to the lowest LOD and LOQ values. The validation parameters for all the three methods are presented in table 9.

The proposed methods were found to be simpler and more rapid, selective, and sensitive than most of the colorimetric methods available in the literature. The statistical parameters and the recovery study data clearly demonstrate the reproducibility and accuracy of the methods. Thus, these methods can be used as an alternative to the existing methods.

\section{CONCLUSION}

Three simple, sensitive, precise and inexpensive visible spectrophotometric methods were developed for estimation of SMZ and TMP in their pure form. Furthermore, the developed methods have an economical advantage and do not need complex requirements needed in chromatographic methods, in addition to the reproducibility as well as the simplicity and convenience. So they can be applied in quality control laboratories for analysis of the studied drugs.

\section{ACKNOWLEDGMENT}

The authors thank Principal and Management, Vaagdevi College of pharmacy, ramnagar, hanmakonda, warangal, india for providing the necessary facilities.

\section{AUTHORS CONTRIBUTIONS}

G. Swetha gave a substantial contribution by data collection, data analysis and interpretation through executing the experimental work in our laboratories. Dr. K. Praveen Kumar drafted the manuscript and extensively revised to improve the quality of the manuscript. Conception, design, critical revision of the article and supervision of the work has been done by Dr. K. Sirisha.

\section{CONFLICTS OF INTERESTS}

The authors have no conflicts of interest

\section{REFERENCES}

1. The United States Pharmacopoeia JSP 23. The National Formulary N F 18, US Pharmacopeial Convention. Edition. USPNF Spanish; 1995. p. 1461-4.

2. Taylor RB, Richards RME, Xing DK. Determination of antibacterial agents in microbiological cultures by highperformance liquid chromatography. Analyst 1990;115:797-9.

3. Takagishi Y, Ohsuga K, Ohama S. Suppository containing sulfamethoxazole/trimethoprim complex and process for preparing the same. U. S. Patent US4461765; 1975.

4. Brogden RN, Carmine AA, Heel RC, Speight TM, Avery GS. Trimethoprim: a review of its antibacterial activity, pharmacokinetics and therapeutic use in urinary tract infections. Drugs 1982;23:405-30.

5. Olajire AA, Chinedum PB, Olayinka AK, Oyakhire 0 . Simultaneous spectrophotometric determination of trimethoprim and sulphamethoxazole following chargetransfer complexation with chloranilic acid. Arabian J Chem 2017;10:S3848-60.

6. Goran S, Elizabeta DS, Marija S, Romel V. Optimization, validation and application of UV-visible spectrophotometriccolorimetric methods for determination of trimethoprim in different medicinal products. Maced Vet Rev 2016;39:65-76.

7. Santosh J, Pradip D, Ajit G, Laxmi J. Simultaneous estimation of trimethoprim and sulfamethoxazole in combined dosage form by UV-spectrophotometric methods. Asian J Pharm Technol Innovation 2015;3:54-62.

8. Zaman SM. Analytical method development for the spectrophotometric determination of sulfamethoxazole in bulk drug and pharmaceutical preparation. J Chem Biochem 2015;3:63-74.

9. Azeez MD, Kiran KB, Manoranjan, Venkateshwarlu G, Manindar B, Naresh Y. Simultaneous determination of sulfamethoxazole and trimethoprim by using a UV-visible spectrophotometer. Int J Pharm Sci Rev Res 2013;23:224-7.

10. Medina JR, Miranda M, Hurtado M, Adriana MD, Ruiz-Segura JC. Simultaneous determination of trimethoprim and sulfamethoxazole in immediate-release oral dosage forms by first-order derivative spectroscopy: application to dissolution studies. Int J Pharm Pharm Sci 2013;5:505-10.

11. Sangita S, Neog M, Dipti D. Development and validation of spectrophotometric methods for estimating sulfamethoxazole in pharmaceutical preparations. Int J Pharm Sci Drug Res 2010;2:204-9.

12. Padmarajaiah N, Shailendra DN, Ashwinee KS, Shivakumar A. A sensitive spectrophotometric method for the determination of sulfonamides in pharmaceutical preparations. Acta Pharm 2007;57:333-42.

13. Ayad Raauf MR, Huda MA, Halah H. Spectrophotometric determination of trimethoprim in pure form and pharmaceutical formulations with metol and potassium hexacyanoferrate (III). Tikrit J Pharm Sci 2012;8:209-20. 
14. Mahmoud RS, Mojgan F, Arezoo HN. Simultaneous spectrophotometric determination of sulfamethoxazole and trimethoprim in pharmaceutical preparations by using multivariate calibration methods. J Appl Chem Res 2010;3:48-52.

15. Pokala RV, Kumari K, Bollikola HB, UV spectrophotometry method development and validation of sulfadiazine and trimethoprim in combined dosage form. Int J Pharm Pharm Sci 2018;10:103-7.

16. Shamsa F, Amani L. Determination of sulfamethoxazole and trimethoprim in pharmaceuticals by visible and UV spectrophotometry. Iran J Pharm Res 2016;1:31-6.

17. Amorim KP, Romualdo LL, Andrade LS. Electrochemical degradation of sulfamethoxazole and trimethoprim at borondoped diamond electrode: performance, kinetics and reaction pathway. Sep Purif Technol 2013;120:319-27.

18. Srinivasa RJ, Vejendla RK, Ravali N, Varnalatha K, Kalpana K. Rapid UPLC method for simultaneous estimation of sulfamethoxazole and trimethoprim in pharmaceutical dosage forms. Indo Am J Pharm Res 2014;4:896-904.

19. Wang JC, Zhang Q, Cai DF. Stability indicating validated HPLC method for analysis of berberine hydrochloride and trimethoprim in the pharmaceutical dosage form. J Chemistry 2013;1-9. http://dx.doi.org/10.1155/2013/360812

20. Kasim LS, Awoyemi AA, Coker HAB, Adepojubello AA, Aziba PI. Chemical evaluation of sulfamethoxazole in some brands of cotrimoxazole. J Res Opinion 2012;2:66-9.

21. Madhulika CH, Anton Smith A, Seetaramaiah K, Kottai Muthu A, Manavalan R. Spectrofluorometric determination of sulphamethoxazole in a pharmaceutical formulation. Int J Pharm Sci Rev Res 2011; 7:198-202.

22. Sabriye P, Ozkorucuklu I, Yucel Sahin II, Guleren AI. Determination of sulfamethoxazole in pharmaceutical formulations by flow injection system/HPLC with potentiometric detection using polypyrrole electrode. J Braz Chem Soc 2011;22:2171-7.

23. Feng, FLY, Zhao C, Tang PLB. Simple colorimetric sensing of trace bleomycin using unmodified gold nanoparticles. Biosens Bioelectron 2011;26:4628-31.

24. Vijayalakshmi R, Sowjanya D, Archana S, Dhanaraju MD. Application of extractive spectrophotometric methods for the determination of flucloxacillin and trandolapril using bromocresol green. Asian J Pharm Clin Res 2014;7:216-8.

25. Ginting N, Silalahi J, Pardede TR, Sudarmi S, Nerdy N. Effect of harvesting time at morning, afternoon, and evening on nitrate and nitrite level in spinach (amaranthus tricolor l.) and mustard (brassica rapa l.). Asian J Pharm Clin Res 2018;11:110-3.

26. Jiao K, Sun W, Zhang S, Sun G. Application of $p$ phenylenediamine as an electrochemical substrate in a peroxidase-mediated voltammetric enzyme immunoassay. Anal Chim Acta 2000;413:71-8.

27. Vogel's textbook of quantitative chemical analysis. Mendham J, Denney RC, Barnes JD, Thomas MJK. 6th ed. Singapore: Pearson education ltd; 2000. p. 165.

28. Sharma S, Neog M, Dabhi D. Development and validation of spectrophotometric methods for estimating sulfamethoxazole in pharmaceutical preparations. Int J Pharm Sci Drug Res 2010;2:204-9.

29. Shamsa F, Amani L. Determination of sulfamethoxazole and trimethoprim in pharmaceuticals by visible and uv spectrophotometry. Iran J Pharm Res 2006;1:31-6.

30. Nagaraja P, Sunitha KR, Vasantha RA, Yathirajan HS Iminodibenzyl as a novel coupling agent for the spectrophotometric determination of sulfonamide derivatives. Eur J Pharm Biopharm 2002;53:187-92.

31. International Conference of Harmonization. Validation of analytical procedures: Text and methodology. Geneva, Switzerland: ICH Q2 [R1]; 2005.

32. Miller JN, Miller JC. Statistics and chemometrics for analytical chemistry, Prentice Hall/Pearson, Harlow, England; 2010.

33. Ramadan AA, Mandil H, Dahhan M. Spectrophotometric determination of cefixime in pure form and in syrian pharmaceuticals through complexation with $\mathrm{Cu}$ (II). Asian J Chem 2013;25:3457-62.

34. British Pharmacopoeia. Vol. I. Her Majesty's Stationary Office, Published by the British Pharmacopoeia Commission; London: 1998. p. $1620,1952$.

35. United States Pharmacopoeia XXIV, USP Convention, Inc. Rockville: MD 20852; 2000. p. 496, 1560. 